\title{
KNOWLEDGE REPRESENTATION DATABASE FOR THE DEVELOPMENT OF TOLERANCES AND FITS IN DESIGN
}

\author{
Romanescu, M. C.; Pruna, L.; Antonescu, I. \& Anghel, A.
}

Abstract: This paper describes the architecture of TFDES (Tolerances and Fits in Design Expert System), an expert system for fit choosing in a CAD (Computer Aided Design) environment and presents how recent improvements in the openness and functionality of tolerances and fits in design system have made a major contribution for a notable expert system. A logical algorithm is developed on computer software with user-friendly interface. The algorithm generates an optimum layout considering factors such as the relevant ISO tolerance and fits on surface-finish information in the decision process. The computer generated solutions compare extremely favourably with laborious trial and error industrial practices.

Key words: tolerance, fit, expert system, $C A D$ design
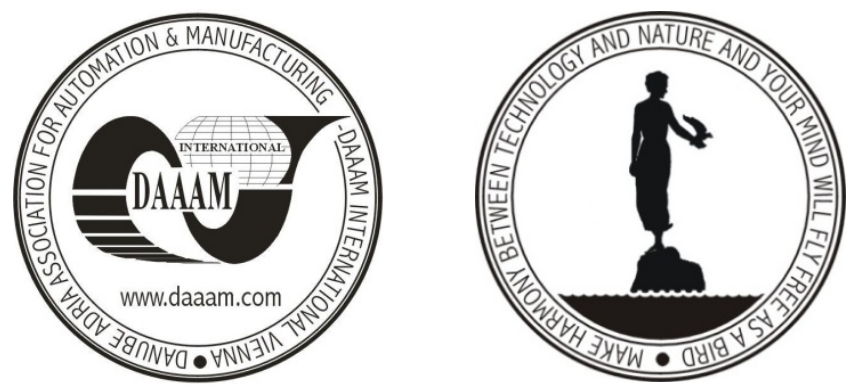

Authors' data: Lecturer, Ph.D. Romanescu, M[aria] C[amelia]; Assoc. Prof. Ph.D. Pruna, L[iviu]; Dr. Antonescu, I[on]; Lecturer, Ph.D. Anghel, A[lina], "Gheorghe Asachi" Technical University, D.Mangeron 67, 700050, Iasi, Romania, rcameliamaria@yahoo.com, lpruna2004@yahoo.com, ianton@rubio.tuiasi.ro, a.a.anghel@gmail.com

This Publication has to be referred as: Romanescu, M[aria] C[amelia]; Pruna L[iviu]; Antonescu, I[on] \& Anghel, A[lina] (2009). Knowledge Representation Database for the Development of Tolerances and Fits in Design, Chapter 92 in DAAAM International Scientific Book 2009, pp. 939-950, B. Katalinic (Ed.), Published by DAAAM International, ISBN 978-3-901509-69-8, ISSN 1726-9687, Vienna, Austria

DOI: 10.2507/daaam.scibook.2009.92 